\title{
Studies on Physical Properties of Maize (Zea mays L.) Seeds
}

\author{
Inderpal Singh Brar*, Anoop Kumar Dixit, Rohinish Khurana and Anand Gautam \\ Department of Farm Machinery and Power Engineering, Punjab Agricultural University, \\ Ludhiana - 141004, Punjab, India \\ *Corresponding author
}

\begin{tabular}{|c|c|}
\hline & A B S T R A C T \\
\hline & \multirow{6}{*}{$\begin{array}{l}\text { Maize (Zea mays L) is one of the most versatile emerging cereal crops having wider } \\
\text { adaptability under varied agro-climatic conditions. Pre and post harvesting operations are } \\
\text { the most labour intensive operations that are presently done manually in India and need to } \\
\text { be mechanized. The physical properties of seeds play an important role for designing seed } \\
\text { metering device. Three varieties of maize seed PMH-1, PMH- } 10 \text { and PIONEER-3396 } \\
\text { were evaluated for their engineering properties in the laboratory. Therefore, the physical } \\
\text { properties of the maize seeds such as size, shape, hundred grain weight, angle of repose, } \\
\text { bulk density and coefficient of static friction are important from engineering point of view } \\
\text { and were studied for the development of metering mechanism of maize planter. Fifty seeds } \\
\text { of each variety (PMH-1, PMH-10 and PIONEER-3396) were tested and observed for } \\
\text { shape and size of the seeds. During observations their geometric mean diameter comes out } \\
\text { to be } 7.33 \mathrm{~mm}, 7.06 \mathrm{~mm} \text { and } 7.68 \mathrm{~mm} \text { for PMH-1, PMH-10 and PIONEER-3396, } \\
\text { respectively. The average value of angle of repose during study was observed to be } 28.59^{\circ} \text {, } \\
27.10^{\circ} \text { and } 28.66^{\circ} \text { for PMH-1, PMH-10 and PIONEER-3396, respectively. The roundness } \\
\text { observed in the laboratory was } 0.74,0.74 \text { and } 0.66 \text { and their sphericity was } 0.78,0.79 \text { and } \\
0.75 \text { for PMH-1, PMH-10 and PIONEER-3396, respectively. Bulk density for the three } \\
\text { varieties of maize was } 733.88 \mathrm{kgm}^{-3}, 750.01 \mathrm{kgm}^{-3}, 741.27 \mathrm{kgm}{ }^{-3} \text { and the value of } \\
\text { Coefficient of static friction was } 0.64,0.58 \text { and } 0.55 \text { for PMH-1, PMH-10 and PIONEER- } \\
3396 \text {, respectively. }\end{array}$} \\
\hline Keywords & \\
\hline $\begin{array}{l}\text { Maize, Physical } \\
\text { properties, PMH-1, } \\
\text { PMH-10, } \\
\text { PIONEER-3396. }\end{array}$ & \\
\hline Articl & \\
\hline $\begin{array}{l}\text { Accepted: } \\
\text { 10 Septem } \\
\text { Available } \\
10 \text { Octobe }\end{array}$ & \\
\hline & \\
\hline
\end{tabular}

\section{Introduction}

Maize (Zea mays L) is most versatile emerging crop which has wider adaptability under varied agro-climatic conditions. Globally, it is also known as queen of cereals crops due to its high genetic yield potential value amongst all the cereals crops. The world leading producer of maize in year 2014 in descending order are United States of America (361.09 million tonne), China (215.81 million tonne), Brazil (79.80 million tonne), Argentina (33.80 million tonne),
Ukraine (30.94 million tonne), India (23.67 million tonne), Mexico (23.27million tonne), and Indonesia (19.00 million tonne) (Anon., 2017a).

In India, maize is the third most imperative food cash crop after wheat and rice. During the year 2014-15, the area under cultivation of maize in both the seasons kharif and rabi was 9185.40 thousand hectare with a production of 24.17 million tonne and productivity of 
$2632 \mathrm{kgha}^{-1}$. In year 2014-15 the area under maize cultivation in Punjab was 126.0 thousand hectare with the production of 0.46 million tonne with productivity $3651 \mathrm{kgha}^{-1}$ (Anon., 2017 b).

Maize can be successfully grown in various types of soils varying from loamy sand soil to clay loam soil. Soils having high organic matter content and significant water holding capacity with neutral $\mathrm{pH}$ balance are considered as proficient for high productivity of maize. It requires reasonable moisture content and warmth from germination to flowering. For proper growth 4 to 6 irrigations required depending upon the rain. The most acceptable temperature for germination of seed is $21^{\circ} \mathrm{C}$ to $32^{\circ} \mathrm{C}$ for growth. Extremely high temperature and less humidity during flowering may damage the foliage, desiccate the pollen and obstruct with proper pollination, which results poor grain setting (Anon., 2017c).

Optimum plant stand can be achieved through proper tillage and crop establishment operations, which act as main driver of the high crop productivity. Establishment of crop is a series of events like seeding, germination, emergence and final seed establishment that depend on interactions of seed, soil moisture, seedling depth, sowing method, use of equipments etc. For better establishment of crop under a set of growing situation the methods of planting plays a crucial role. Maize is mostly sown by direct methods like dibbling and with different multi crop planters. However, the sowing method mostly depends on number of factors viz. the complex interaction over time of seeding, soil, weather conditions, machinery, biotic, management season and cropping system etc. (Anon., 2017d).

Generally, maize seeds are sown manually by hand for small scale farming. For large scale production generally horizontal and inclined plate planters are used by the farmers. Mechanical drilling methods or planters for sowing of seeds influence mainly the depth of seeding, precise placement of seeds and uniformity of seed placement results in higher yield as differentiated to that in manual planting (Mona et al., 2009). Uniform spacing of seeds increases crop yield and non-uniform spacing lesser yield (Searle et al., 2008). During the cultivation of maize sowing, thinning, weeding and harvesting are the most labour intensive operations that are presently done manually in India, because of high labour, the area under maize cultivation is low which can be increased by mechanization of this crop in India.

Irregular shaped seeds lead to variation and placement of the seeds when sown using existing planters on the other hand, pneumatic planters have been developed in India but are not popular due to high initial cost of machine and lack of repair and maintenance facilities.

Due to this reason farmers resort to dibbling method for sowing of the seed which results in more time and labour consumption. Hence, there is a need for precise and economical specialized equipment in India for direct planting of maize crop to reduce labour requirement and input costs. In order to overcome this problem, the development of a precise metering mechanism for sowing of maize seed was needed which could provide higher seed singulation and minimum seed missing in the field and study of engineering properties of maize seeds is most important for this development. Therefore, the physical properties of the maize seeds such as size, shape, test weight, angle of repose, bulk density and coefficient of static friction were studied. In recent years, physical properties have been studied by various researchers for various crops such as onion seed (Chhina and Sharma, 2011); coriander seed (Coskuner and 
Karababa, 2007); millet (Baryeh, 2002); quiona seed (Vilche et al., 2003): almond nut and kernel (Aydin, 2003) and for Arigo seeds (Davies, 2010).

\section{Materials and Methods}

\section{Selection of the varieties}

Three varieties of the maize were selected for the study. PMH-1 and PMH-10 was recommended by Punjab Agricultural University, Ludhiana because these two varieties cover major area under maize in Punjab region and PIONEER-3396 is commercially available variety which cover more area compare to other nonrecommended verities in Punjab.

\section{Moisture content of the maize seed}

Moisture content of the samples was determined according to AOAC approved vacuum oven method (AOAC, 1990). Since transportation, storage and handling operations of the seeds are performed in this moisture range. All the experiments were replicated ten times and the average values were reported.

\section{Size and shape of the seed}

Vernier caliper was used to measure the size and shape of maize seeds. Sample size of 50 seeds of each variety was selected randomly for the size and shape study. Seeds were measured about their three principle axis as shown in Figure 1. The dimensions of the randomly selected fifty seeds were measured for each variety. Further, geometric mean diameter $(D P)$ and spherecity $(\varphi)$ of the seeds were calculated using the following relationship in equations (2.1) and (2.2), respectively (Mohsenin, 1980).

$D P=\sqrt[\mathbb{s}]{L W T}(2.1)$
Where, $L=\operatorname{length}(\mathrm{mm}), W=$ width $(\mathrm{mm}), T=\operatorname{thickness}(\mathrm{mm})$

The Spherecity $(\varphi)$ was calculated using the following equation (Mohsenin, 1970)

$\varphi=(\sqrt[\mathbb{s}]{L W T} / L)(2.2)$

Where, $L=\operatorname{length}(\mathrm{mm}), W=$ width $(\mathrm{mm}), T=\operatorname{thickness}(\mathrm{mm})$

\section{Roundness}

The trace of the seed was done on the graph paper and the area under the trace was measured by measuring the squares within it for measuring roundness of seed. The area of the closest circle in the seed area was also computed. The ratio of these two gives the roundness. Measuring roundness with calipers was slow and tedious. Seed property analyzer calculate roundness with equation (2.3), (Gautam et al., 2016)

$$
\text { Roundness }=[(W / L)+(T / L)+(T / W)] / 3
$$

\section{Test weight}

Test weight was determined for five random samples of each variety on an electronic balance having least count of $0.001 \mathrm{~g}$. One hundred seeds were counted manually and thereafter weighed on an electronic balance.

\section{Angle of repose}

The angle of repose can be measured by measuring the height of the heap and the diameter of heap formed by the seeds (Kaleemullah and Gunasekar, 2002). For the determination of angle of repose of maize seed, a plastic cylinder (inner diameter $70 \mathrm{~mm}$ and height $270 \mathrm{~mm}$ ) shown in Figure 2 was kept vertically on horizontal wooden 
surface and filled with sample. Tapping during filling was done to obtain uniform packing and to minimize the wall effect, if any. The cylinder was raised above slowly so that whole material could slide freely to form a heap. The height of the heap $(\mathrm{H})$ and the diameter of the heap (D) were measured with the help of measuring scale and the angle of repose $(\varphi)$ of maize seed was computed using equation (2.4) (Bart-Plange and Baryeh, 2003).

$\varphi=\tan ^{-1}(2 H / D)(2.4)$

\section{Bulk density}

The bulk density is the ratio of the mass sample of the seeds to its total volume which was calibrated in $\mathrm{kgm}^{-3}$. The bulk density of the maize seeds at the desired moisture content was determined by filling a $100 \mathrm{ml}$ container with the seeds, then weighing the contents on an electronic balance and the process was replicated 10 times (Deshpande et al., 1993; Mohsenin, 1970)

\section{Coefficient of static friction}

Mild steel (MS) surface was used to determine the coefficient of static friction of maize seed. A table top arrangement was used shown in figure (Jha and Prasad, 1993; Jha, 1999). The arrangement consists of a wooden box having dimensions of $10.5 \times 10.5 \times 5 \mathrm{~cm}^{3}$, connected to a hanging weight carrier (pan) by means of string (having negligible mass) which passed over pulley of negligible friction fixed on one end of the table. The dimensions of the box $\left(10.5 \times 10.5 \times 5 \mathrm{~cm}^{3}\right)$ was so selected to ensure that the total contact area of maize seed, with a horizontal surface is large enough to resist the force applied tangentially by sliding the whole mass rather than rolling should be sufficient to be measured easily. The wooden box was positioned on a horizontal MS surface. The weights were put into the pan until the box just started to slide. The total weight (W1) was noted. The wooden box was then filled with maize seeds and was slightly raised above the floor to eliminate the effect of the rim of the wooden box in the value of static friction. Weights were again added to the hanging pan in small amounts until the box filled with seed began to just slide on the MS surface. The total weight (W2) required to slide the box on the selected surface was recorded. The weight of the sample (W) was also noted and the coefficient of static friction was computed by the following equation (2.5).

$\mu=(W 2-W 1) / W(2.5)$

\section{Results and Discussion}

\section{Size and shape}

The range of major, intermediate and minor dimensions of the seeds of three different varieties of maize PMH-1, PMH-10 and PIONEER-3396 are given in Table 1. For $\mathrm{PMH}-1$ seed the major dimension varied from $(8.18-10.90 \mathrm{~mm})$, intermediate dimension $(5.67-8.87 \mathrm{~mm})$, and the minor dimension (4.45-6.98 $\mathrm{mm})$ having mean values of 9.32, 7.22 and $5.89 \mathrm{~mm}$ respectively. $\mathrm{PMH}-10$ seed major dimension varied from (7.93-9.98 $\mathrm{mm}$ ), intermediate dimension (5.98-9.94 $\mathrm{mm}$ ) and the minor dimension (4.56-6.79 $\mathrm{mm})$ having mean values 8.86, 7.15 and $5.60 \mathrm{~mm}$ respectively and for PIONEER-3396 seed the major dimension varied from (9.03-11.86 $\mathrm{mm})$, intermediate dimension (6.89-10.02 $\mathrm{mm})$, and the minor dimension (4.28-7.78 $\mathrm{mm}$ ) having mean values of $10.28,8.23$ and $5.4 \mathrm{~mm}$ respectively (Table 1 ). The mean geometric mean diameter of 50 seeds as calculated from these dimensions are found to be $(7.33,7.06$ and $7.68 \mathrm{~mm}$ ) for PMH-1, PMH-10 and PIONEER-3396 maize seeds respectively (Table 1). The shape of the seed in terms of roundness and sphericity was 
studied. There was difference in roundness and sphericity of maize seeds due to difference in varieties (Table 1).

The mean value of roundness of 50 maize seeds was $0.74,0.74$ and 0.66 for three varieties of maize seeds PMH-1, PMH-10 and PIONEER-3396 respectively. The sphericity of maize seeds PMH-1, PMH-10 and PIONEER-3396 was $0.78,0.79$ and 0.75 respectively. The coefficients of variation for roundness and sphericity of these varieties of seeds varied from 3 to 6 percent and 6 to 13 percent respectively. Therefore, the shape of the cell for seed metering plates of the planter could be circular, semi-circular and slant type with characteristic dimensions greater than or equal to the major, intermediate and mean diameter of seed.

\section{Test weight}

The test weight of the different varieties of maize seeds under study are presented in Table 2. Variation in the test weight of different varieties was observed due to different size of maize seed.

Table.1 Size, geometric mean diameter, roundness and spherecity of various varieties maize seeds

\begin{tabular}{|c|c|c|c|c|}
\hline Treatments & & PMH-1 & PMH-10 & PIONEER-3396 \\
\hline \multirow{4}{*}{$\begin{array}{l}\text { Major dimension } \\
\text { (length) }\end{array}$} & Range $(\mathrm{mm})$ & $8.18-10.90$ & $7.93-9.98$ & $9.03-11.86$ \\
\hline & $\operatorname{Mean}(\mathrm{mm})$ & 9.32 & 8.86 & 10.28 \\
\hline & $\mathrm{CV}$ & 0.06 & 0.06 & 0.07 \\
\hline & \pm SD & 0.60 & 0.54 & 0.75 \\
\hline \multirow{4}{*}{$\begin{array}{l}\text { Intermediate } \\
\text { dimension } \\
\text { (Width) }\end{array}$} & Range $(\mathrm{mm})$ & $5.67-8.87$ & $5.98-9.94$ & $6.89-10.02$ \\
\hline & $\operatorname{Mean}(\mathrm{mm})$ & 7.22 & 7.15 & 8.23 \\
\hline & $\mathrm{CV}$ & 0.06 & 0.10 & 0.09 \\
\hline & $\pm \mathrm{SD}$ & 0.45 & 0.71 & 0.70 \\
\hline \multirow{4}{*}{$\begin{array}{l}\text { Minor dimension } \\
\text { (Thickness) }\end{array}$} & Range $(\mathrm{mm})$ & $4.45-6.98$ & $4.56-6.79$ & $4.28-7.78$ \\
\hline & $\operatorname{Mean}(\mathrm{mm})$ & 5.89 & 5.60 & 5.42 \\
\hline & $\mathrm{CV}$ & 0.9 & 0.11 & 0.17 \\
\hline & $\pm \mathrm{SD}$ & 0.53 & 0.63 & 0.97 \\
\hline \multirow{4}{*}{$\begin{array}{l}\text { Geometric mean } \\
\text { diameter }(\text { GMD) }\end{array}$} & Range $(\mathrm{mm})$ & $6.32-8.20$ & $6.46-8.48$ & $7.07-8.51$ \\
\hline & $\operatorname{Mean}(\mathrm{mm})$ & 7.33 & 7.06 & 7.68 \\
\hline & $\mathrm{CV}$ & 0.05 & 0.06 & 0.05 \\
\hline & $\pm \mathrm{SD}$ & 0.35 & 0.39 & 0.39 \\
\hline \multirow{4}{*}{ Sphericity } & Range & $0.61-0.86$ & $0.66-0.87$ & $0.65-0.86$ \\
\hline & Mean & 0.78 & 0.79 & 0.75 \\
\hline & $\mathrm{CV}$ & 0.05 & 0.06 & 0.09 \\
\hline & $\pm \mathrm{SD}$ & 0.03 & 0.04 & 0.06 \\
\hline \multirow{4}{*}{ Roundness } & Range & $0.57-0.83$ & $0.59-0.84$ & $0.57-0.87$ \\
\hline & Mean & 0.74 & 0.74 & 0.66 \\
\hline & $\mathrm{CV}$ & 0.06 & 0.08 & 0.13 \\
\hline & $\pm \mathrm{SD}$ & 0.04 & 0.05 & 0.08 \\
\hline
\end{tabular}


Table.2 Physical properties of various varieties of maize seeds

\begin{tabular}{|l|c|c|c|}
\hline \multicolumn{1}{|c|}{ Treatments } & PMH-1 & PMH-10 & PIONEER-3396 \\
\hline Moisture content $(\boldsymbol{w} \boldsymbol{b}) \%$ & 6.32 & 5.46 & 5.21 \\
\hline Test weight $(\mathbf{1 0 0}$ seeds) $(\boldsymbol{g})$ & 29.09 & 28.56 & 29.80 \\
\hline Angle of repose $($ degree $)$ & 28.59 & 27.10 & 28.66 \\
\hline Bulk density $\left(\mathbf{k g m}^{-\mathbf{3}}\right)$ & 733.88 & 750.01 & 741.27 \\
\hline Coefficient of static friction & 0.64 & 0.58 & 0.55 \\
\hline Seed germination $(\boldsymbol{\%})$ & 89.33 & 87.64 & 97.00 \\
\hline
\end{tabular}

Fig.1 Characteristics dimensions of maize

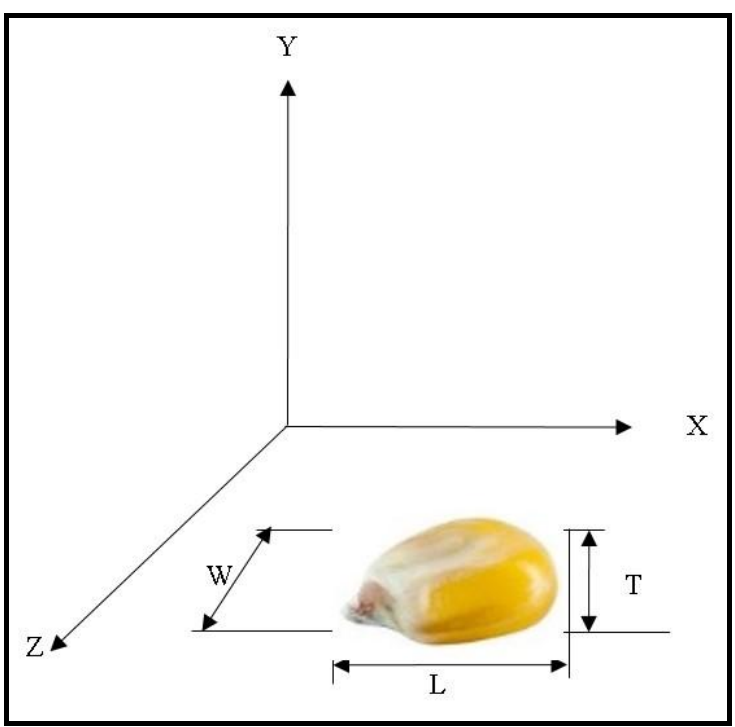

Fig.2 Apparatus for calculating physical properties of maize seed

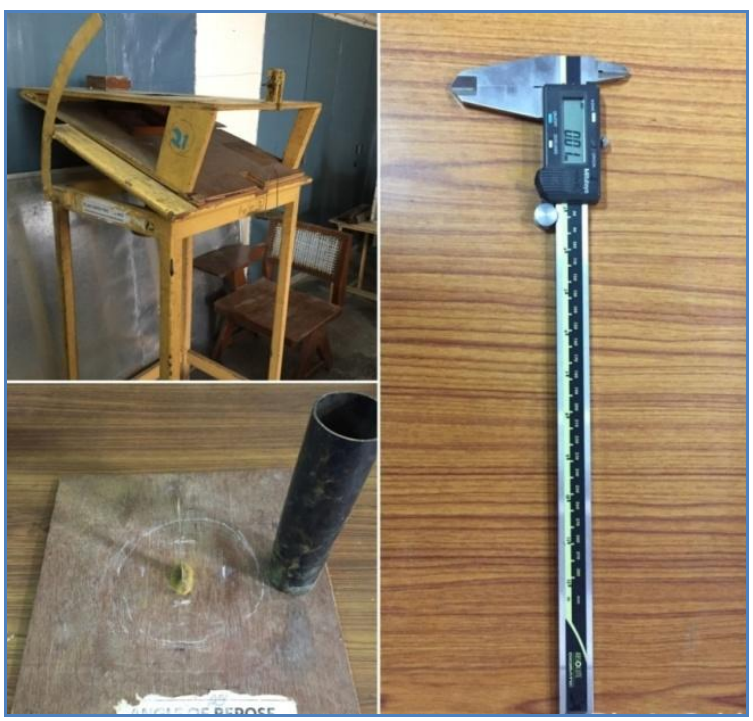


Fig.3 Seed germination of PIONEER-3396, PMH-1 and PMH-10 seeds

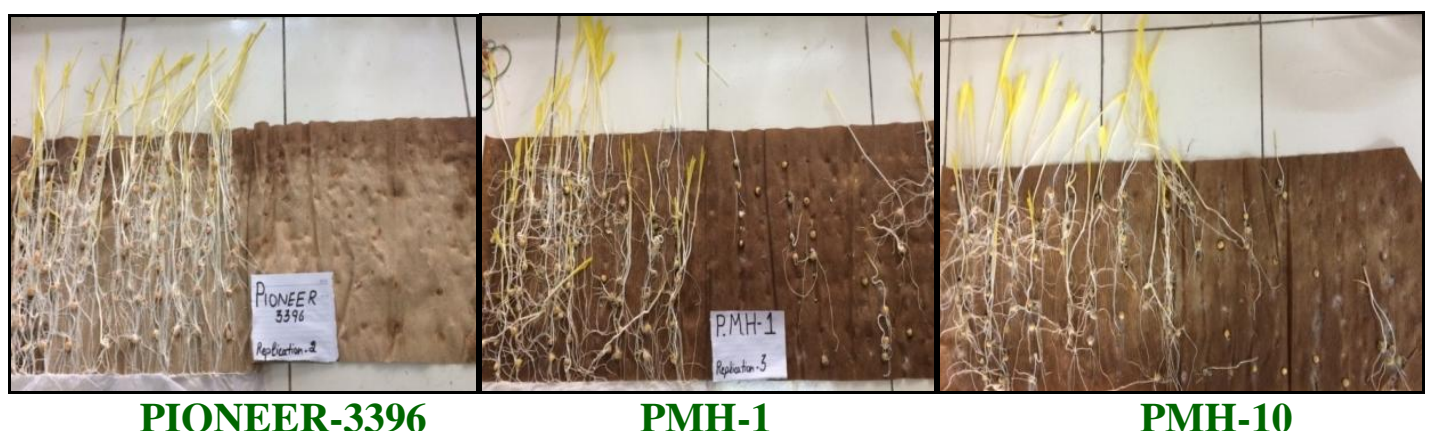

The average value of hundred grain weight for PMH-1, PMH-10 and PIONEER-3396 maize seeds are 29.09, 28.56 and $29.80 \mathrm{~g}$ respectively.

Thus, there are very less variation in the test weight of these three varieties given in Table 2 .

\section{Angle of repose}

Angle of repose of the seed of maize variety (PMH-1, PIONEER-3396 and PMH-10) is given in the Table 2 .

The average values of angle of repose for PMH-1, PIONEER-3396 and PMH-10 were $28.59^{\circ}, 27.10^{\circ}$ and $28.66^{\circ}$, respectively.

\section{Bulk density}

The bulk density is the important parameter for design of seed hopper of the average value of bulk density was observed to be $733.88,750.01$ and $741.27 \mathrm{kgm}^{-3}$, respectively for the seeds of PMH-1, PMH-10 and PIONEER-3396 varieties (Table 2).

\section{Coefficient of static friction}

The values for coefficient static friction for PMH-1, PMH-10 and PIONEER-3396 maize varieties were found $0.64,0.58$ and 0.55 , respectively (Table 2 ).

Seed germination

Seed germination test of three varieties of maize (PMH-1, PMH-10, and PIONEER3396) was conducted in the laboratory (Figure 1). Average seed germination of $\mathrm{PMH}-1$, PMH-10 and PIONEER-3396 was 89.33\%, $87.64 \%$ and $97 \%$, respectively (Table 2 ).

There was difference in roundness and sphericity of maize seeds due to difference in their varieties. The coefficients of variation for roundness and sphericity of these varieties of seeds varied from 3 to 6 percent and 6 to 13 percent respectively. Therefore, the shape of the cell for seed metering plates of the planter could be circular, semi-circular and slant type with characteristic dimensions greater than or equal to the major, intermediate and mean diameter of seed.

\section{References}

Anonymous, 2017a. India position in production of maize in the world. http://www.indiastat.com/table/agricultu re/2/maize/17199/897969/data.aspx (Date of visit: 7thJuly, 2017).

Anonymous, 2017b. State/Season-wise area and production for maize in India 
http://www.indiastat.com/table/agricultu re/2/maize/17199/80071/data.aspx

(Date of visit: 7th July, 2017).

Anonymous, 2017d. Maize production technologies in India. http://farmer.gov.in/cropstaticsmaize.ht $\mathrm{ml}$ (Date of visit: 7th July, 2017).

AOAC, 1990. Official methods of analysis of the AOAC (15thed.). Arlington, VA: Association of Official Analytical Chemists, Inc.

Aydin, C., 2003. Physical properties of almond nut and kernel. J Food Engg 60, $315-20$.

Bart-Plange, A., Baryeh, E. A., 2003. The physical properties of category B cocoa beans. J Food Engg 60: 219-27.

Baryeh, E.A., 2002. Physical properties of millet. J Food Engg 51, 39-46.

Chhina, R. S., Sharma, A. D., 2011. Studies on physical properties of onion seed (Allium cepa L). ProgHortic 43(1): 7680.

Coskuner, Y., Karababa, E., 2007. Physical properties of coriander seeds (Coriandrum sativum L.). J Food Engg 80 (2), 408-416.

Davies, R.M., 2010. Some physical properties of arigo seeds. International Agrophys 2010, 24, 89-92.

Deshpande, S.D., Bal, S., Ojha, T.P., 1993. Physical properties of soybean seeds. J Agri Engg Res 56, 89-92.

Gautam, A., Khurana, R., Manes, G.S., Dixit, A.K., 2016. Studies on Engineering Properties of Pelleted Carrot (Daucus carota L.) Seeds, International Journal of Bio-resource and Stress Management 2016, 7(5):1044-48.

Jha, S.N., 1999. Physical and hygroscopic properties of makhana. J Agric. Engg. Res, 72: 145-150.

Jha, S.N., Prasad, S., 1993. Physical and thermal properties of gorgon nut. J Food Process Engg 16, 237-245

Kaleemullah, S., Gunasekar, J.J., 2002. Moisture dependent physical properties of areca nut kernels. Biosystem Engineering., 82: 331-338.

Mohsenin, N.N., 1970. Physical Properties of plant and animal materials. New York: Gordon and Breach Science Publishers.

Mohsenin, N.N., 1980. Physical Properties of plant and animal materials. Gordon and Breach Science Publisher. New York.

Mona, M. A., Islam, H., Khater, M.M., Baran, Y., 2009. Effect of field size on mechanical wheat seeder performance in reclaimed lands of Egypt. Tanm Makinalari Bilimi Desrgis Journal of Agricultural Machinery Science, 5(1): 45-51.

Searle, C. L., Kocher, M.F., Smith, J.A., Blankenship, E.E., 2008. Field slope effects on uniformity of corn seed spacing for three precision planter metering systems. Biological Systems Engineering: Papers and Publications. Paper 151.

Vilche, C., Gely, M., Santalla, E., 2003. Physical properties of quinoa seeds. Bio systems Engineering 86(1), 59-65.

\section{How to cite this article:}

Inderpal Singh Brar, Anoop Kumar Dixit, Rohinish Khurana and Anand Gautam. 2017. Studies on Physical Properties of Maize (Zea mays L.) Seeds. Int.J.Curr.Microbiol.App.Sci. 6(10): 963970. doi: https://doi.org/10.20546/ijcmas.2017.610.116 